\title{
Surgical treatment of female stress incontinence: impact of changed views on polypropylene
}

\author{
John P. F. A. Heesakkers - J.-P. Roovers - Steven E. Schraffordt Koops
}

Accepted: 28 July 2021 / Published online: 3 September 2021

(C) The Author(s) 2021

\begin{abstract}
The introduction of the tensionfree vaginal tape in 1995 drastically changed the landscape of surgical procedures for stress urinary incontinence (SUI). Because of the uncomplicated technique many urologists and gynecologists embraced the procedure with tripled the number of annual procedures in the beginning of this century. At the same time polypropylene was used for the development of surgical procedures of pelvic organ prolapse (POP). Especially the use of polypropylene for POP has caused many severe clinical complications. This caused a huge reduction of these kind of surgical procedures and it is performed nowadays only under strict conditions. At the same time the use of polypropylene for SUI was scrutinized and questioned. Nowadays, in the Ango-Saxon countries the use of polypropylene tapes for SUI is not recommended. This manuscript explores the role of polypropylene tapes for SUI. Questions that are dealt with are: How dangerous are polypropylene tapes any-

way? What are the alternatives? Which factors contribute to a successful outcome of stress incontinence surgery?
\end{abstract}

Keywords Mesh - Tape - Polypropylene · Complications · Mid urethral sling (MUS)

Prof. J. P. F. A. Heesakkers, MD PhD (ه)

Department of Urology, Maastricht University Medical Center (MUMC+), Maastricht, The Netherlands

john.heesakkers@mumc.nl

Prof. J.-P. Roovers, MD PhD

Department of Gynecology, Amsterdam University Medical Center, Amsterdam, The Netherlands

S. E. Schraffordt Koops, MD PhD

Department of Gynecology, Meander Medical Center, Amersfoort, The Netherlands

\section{Chirurgische behandeling van stressincontinentie bij vrouwen: de impact van een andere kijk op polypropyleen}

Samenvatting De introductie van de tensionfree vaginal tape van polypropyleen in 1995, heeft het operatieve landschap van de behandeling van stressincontinentie (SUI) danig veranderd. Door de relatief eenvoudige techniek kwam deze operatie binnen het armamentarium van veel urologen en gynaecologen. Dit had als gevolg dat het aantal operaties voor stressincontinentie verdrievoudigde. Tegelijkertijd werden operatieve behandelingen voor prolaps ontwikkeld waarbij hetzelfde materiaal werd gebruikt. Met name de operatieve behandeling van prolaps met kunststof heeft veel problemen veroorzaakt. Vandaar dat het aantal operaties in deze vorm dramatisch is gedaald en alleen nog onder zeer specifieke condities wordt gedaan. Daarnaast rees de vraag of het gebruik van polypropyleen voor SUI net zoveel problemen oplevert en of deze techniek ook aan banden gelegd zou moeten worden. In de Angelsaksische landen wordt het gebruik van polypropyleen voor SUI afgeraden, mede op basis van niet-medische argumenten. Dit artikel gaat in op de positie van tapes van polypropyleen voor SUI. De vragen die behandeld worden zijn: hoe gevaarlijk zijn tapes van polypropyleen eigenlijk, wat zijn de alternatieven en welke factoren zijn van belang om bij SUI te komen tot een succesvol operatieresultaat.

Trefwoorden Mesh · Tape · Polypropyleen · Complicaties · Midurethrale sling (MUS)

\section{Introduction}

Since several years we face a discussion on how to deal with implants made of PolyPropylene (PP) for benign disorders such as pelvic organ prolapse (POP) and 
stress urinary incontinence (SUI) in women. Tensionfree midurethral tapes, mostly made of PP, were introduced in 1995 by Ulmsten and Petros [1]. The procedure they described, and the results reported for tapes dramatically changed the treatment for female SUI. Since the introduction of these polypropylene MidUrethral Slings (MUS) the number of surgical procedures for SUI increased exponentially. The explanations were that the procedure is minimally invasive, can be performed in daycare setting, has a quick recovery time and good functional results and a low complication rate [2]. Therefore, these tapes are well appreciated by as well patients, surgeons and health insurers.

The classic alternative surgical solutions for SUI such as the autologous fascia sling, Burch- and needle-colposuspensions and peri- and trans-urethral injectables have another profile. Slings and colposuspensions are perhaps equally effective, but these procedures are more invasive and involve a longer recovery time. Bulk material is simply less effective. This means that patients and surgeons are more hesitant to use these techniques and the number of women undergoing surgery with one of these options is far less than those choosing a midurethral tape. Perhaps in older days women suffering from SUI were undertreated until the introduction of the MUS. On the flipside, since it is relatively easy to put in a tape, it is perhaps also performed by less skilled surgeons with all consequences. Recently mid-urethral tapes are heavily scrutinized because they are made of PP, the same material that was used for POP repair which caused many severe complications. In this manuscript we will first depict the international activities that developed after the worries about polypropylene. Afterwards we try to answer the obvious questions that can be raised and which are listed here under. These questions are:

1. How dangerous are polypropylene tapes?

2. What are the alternatives?

3. Which factors contribute to a successful outcome of stress incontinence surgery?

\section{International regulatory actions from 2003 onwards and industry response}

After the US Food and Drug Administration (FDA) warnings in 2011 a cascade of actions followed [3]. Beginning in 2012, FDA ordered manufacturers of urogynecologic surgical mesh devices to perform post market surveillance studies ("so called 522 studies in the FDA terminology") to address specific safety and effectiveness concerns related to the use of mini-slings for treatment of SUI. According to FDA, the orders were based on evaluation of published literature, analysis of reported adverse events, and feedback from the 2011 Obstetrics and Gynecology Devices Panel of the Medical Device Advisory Committee. By mid-February 2013, FDA issued 14 postmarket study orders to seven manufacturers. The most recent milestone was on April 16, 2019, when the FDA ordered manufacturers of surgical mesh intended for transvaginal repair of Pelvic Organ Prolapse (POP) to stop selling and distributing these products. In the USA the use of synthetic MUS is not prohibited by the FDA [4].

The USA suffers under an enormous amount of law suits though on all sorts of implants. Souders et al. published on litigation in the USA on transvaginal use of mesh [5]. This article describes 73,915 claims of which a $1 \%$ sample showed $63.3 \%$ for SUI, $13.3 \%$ for POP and $23.2 \%$ involving both. The lawsuits in the US have often resulted in settlements for large amounts of money.

In the UK several reviews were published: the Scottish review, the Welsh review and the NHS review. After these reviews all use of mesh (for POP and stress urinary incontinence) was banned in the UK [6]. The situation in the UK is aberrant as the National Institute for health and Care Excellence (NICE), based their 2019 advise on scientific evidence does recommend the use of polypropylene MUS Procedures as intervention for SUI [7]. A recent report of the Independent Medicines and medical Devices Safety Review in the UK has imposed strict ruling which need to be followed before this ban on mesh will be relieved [8].

In Australia and New Zealand also, strict ruling was implied by the authorities with a complete ban on mesh used for trans vaginal POP surgery and a ban of the single incision sling for urinary stress incontinence $[9,10]$. In November 2019 three women won a class action at the federal court of Australia. The court ruled that the company (J\&J) had misled consumers about the risks involved with their mesh products for POP and SUI. The ruling was based on the Australian negligence law. The ruling implies that all women feeling injured can now seek for financial compensation. The judge stated that the 'long term effects are currently not known reliable'. The judge based her ruling on a review article from Cody et al. dating from 2003 on MUS [11]. Since then, multiple articles and Cochrane reviews have been published stating satisfactory long-term outcome and a 'good safety profile'.

The Medicines and Health-care Products and Regulatory Agency (MHRA) in Europe concluded after reviewing all information available in 2014 that the use of mesh implants used for SUI are safe and that the overall benefits outweigh the relative low rate of complications [12].

The European Commission has published the SCENIHR, a document supporting the routine use of mesh for MUS [13]. The commission states that; 'synthetic sling surgery is an accepted procedure with proven efficacy and safety used by an experienced and appropriately trained surgeon'.

The European urologists and gynaecologists wrote a consensus statement about the use of mesh in pelvic floor surgery in 2017. One of the main conclusions 
was that the use of synthetic MUSs for surgical treatment of SUI in both male and female patients has good efficacy and acceptable morbidity [14].

\section{How dangerous are polypropylene tapes?}

The synthetic MUS is throughout the world the most described kind of surgery to be found in scientific literature [2]. Hence the different complications perioperative but also long-term complications have been described extensively [15]. Peri-operative complications described are bladder perforation, other visceral tract injuries, blood-loss, urethral lesion, post-operative hematoma, fever, urinary tract infection, post micturition urine residual. The Cochrane review study from 2017 has marked these peri-operative complication rates as low [2]. Long-term complications to be considered are: voiding dysfunction, recurrent stress incontinence, pain (chronic pelvic, retropubic, groin pain, dyspareunia) and erosion. The same Cochrane review stated that the evidence indicates an overall positive effect for the use of synthetic mid urethral slings.

In total 41 different MUS were introduced until 2012 [16]. Many of these options are or were on the market in several different sorts of mesh type like Gore-Tex, Mersilene, PTFE meshes (type II), silicone coated polyethylene or polyester (type IV), polypropylene none knitted or non-woven mesh. Of all these different sorts of meshes and options/usage many have been taken from the market because of high complication rates found at clinical research [16]. The complication rates between the way implants and which exact sort of material is used also differ enormously. Nowadays throughout the world only type I knotted polypropylene is used.

\section{Erosion/exposure/extrusion/perforation}

The term erosion is usually used but does not suit the different clinical scenarios, however mostly the term erosion is used for exposure, extrusion and perforation. The International Urogynecological Association (IUGA) and International Continence Society (ICS) jointly published the terminology and classification [17]. The different clinical diagnosis are:

Exposition: A condition of displaying, revealing, exhibiting, or making accessible.

Perforation: abnormal opening into a hollow organ or viscus. Extrusion: passage gradually out of a body structure or tissue (e.g., a loop of tape protruding into the vaginal cavity).

MacCraith reported in a very recent review on tapes placed in 283,000 women $1.9 \%$ erosion or exposure after a mean of 261 days post implant [18]. GurolUrganci and colleagues retrospectively analyzed data of nearly 100,000 women who underwent surgery with a primary MUS for SUI [19]. All the procedures were carried out in National Health Service (NHS) hospitals in England between 2006 and 2015. The focus was on complications, especially removal of the tape and reoperation because of recurrent SUI. The nine-year removal rate was $3.3 \%$. The reoperation rate for SUI was $4.5 \%$ at 9 years post-operative. A total of $7 \%$ of the women had undergone surgery for either of these reasons after 9 years.

On cellular levels no firm studies exist on local tissue response caused by or affecting erosion. Only one human study has shown that polypropylene midurethral slings induce a minimal inflammatory reaction without significant change in collagen solubility, in comparison to multifilament slings (Mersilene) [20]. Up to 2021 it is not possible to confirm that observed changes in the types of cells are linked to an immunologic reaction or to the exposure to polypropylene itself. The authors came to the conclusion that polypropylene degradation may play a role in a continuous local inflammatory response, resulting in mesh hardening and late deformations. However, these concepts remain very controversial and speculative based on limited evidence.

\section{Autoimmune disease}

The non-medical society suggestions are that synthetic materials used for MUS can be a trigger for autoimmune inflammatory disease. These suggestions follow a case study which was performed in an autoimmune clinic [21]. In this study 714 patients were selected. In 40 of these patients mesh implants were present: 18 patients after a hernia repair, 22 after vaginal mesh implant, 4 TVT's and 4 mesh implants for POP, not further described. 39/40 Presented with fatigue, 38/40 with myalgia/muscle weakness, 36/40 with arthralgias/arthritis $31 / 40$ had cognitive symptoms like memory loss $32 / 40$ with pyrexia, 34/40 had dry eyes/mouth, 7/40 developed stroke like symptoms. According to this manuscript all these symptoms were related to the PP mesh implants. The study of Chughtai is of a better quality [22]. This matched control study involved 2102 patients with a vaginal mesh implant and control groups without implants. In this study showed no relation between autoimmune disease and the use of PP implants was found.

\section{De novo malignancy}

A Swedish study assessed the association between the implantation of polypropylene tapes for the treatment of SUI and carcinogenesis on 20,905 exposed women in the general population. There were no significant differences in risk between exposed and unexposed women for pelvic organ cancers including ovarian, endometrial, cervical, bladder and urethral malignancies [23]. 
Pain

Persisting post-operative pain is one of the most feared complications by patients and doctors. Lack of recognition and therefore also poor treatment for patients, has led to most of the public opinion against the use of mesh. Chronic pain was the main reason in the report of the Independent Medicines and medical Devices Safety Review in the UK for the ban on mesh surgery [8]. This and many other reports are mainly based on reviews of patients. The problem with all patient reviews and retrospective research into pain as a complication is the lack of information. Unknown type of implant used, the sort of surgery the patient underwent, but also what the complication incidence was for a specific type and usage. To avoid alternative facts, one needs the denominator-i.e., how many patients underwent a specific sort of surgery and with which specific mesh, as already many tapes have been taken of the market. With retrospective studies pre-operative pain is not recorded. Whether the pain already existed per-operative than remains unclear. Noncyclical pain lasting longer than 6 months is a very common problem for many women. According the WHO review, $5.7-26.6 \%$ of women is affected [24]. This makes the pre-operative pain status of major importance when reviewing post-operative pain. One can compare pain rates though, in a large recent review study 292,606 patients for POP surgery and 283,529 MUS patients from 26 studies were included to compare the rates of erosion and chronic pain after POP and SUI surgery with mesh [18]. The incidence for chronic pain was significantly higher in the POP group $(6.7 \%$ vs $0.6 \%)$. One of the included RCT's described $4.32 \%$ of patients developing pain, but only $1.4 \%$ needed reintervention after 9 years. This might be a result of the subjectivity and severity of the pain suffered [25].

\section{Dyspareunia/sexual function}

Contradictory results of the effect of TVT on sexual function have been described. Dyspareunia after surgery occurs but also other negative effects have been described as decreased genital sensation, discomfort, diminished arousal and vaginal lubrication. These symptoms can inhibit orgasm. Several options for treatment are possible, estrogen usage, lubricants, pain medication and when all fails removal of the mesh is an option. Several articles explain this morbidity by diminished innervation of vaginal anterior wall, clitoris and enigmatic G-spot after placement of TVT. Removal in these worse case scenarios showed to have a positive effect on desire arousal lubrication, satisfaction and pain [26].

However overall, almost every article published on sexual function described an improvement in function. This positive effect of the TVT results from significant relief of penetration incontinence, coital in- continence and reduced negative emotions during sex [27].

A recent large review article by Alwaal including TVT's and TOT's described an overall improvement for the sexual function [28]. Although a small percentage of women developed de novo dyspareunia, the tradeoff found, was less coital incontinence, reduction of anxiety and avoidance of sex, improved selfimage and body image. De novo dyspareunia was often found after incorrect placement or other complications like erosion or abnormal scare formation.

The Cochrane analysis from 2017 on mid-urethral sling operations for stress urinary incontinence in women found in total 13 trials addressing the sexual function. The studies used besides direct questioning, a variety or one validated questionnaire; the Prolapse/Incontinence Symptoms Questionnaire (PISQ-12), Bristol Female Lower Urinary Tract Symptoms questionnaire (BFLUTS), International Consultation on Incontinence Questionnaire Lower Urinary Tract Symptoms quality of life questionnaire (ICIQLUTSqol) and Visual Analogue Scale (VAS). After a follow-up from 6-24 months all studies showed an overall improvement of sexual function. The rate of dyspareunia found was low [2].

\section{Wat are the alternatives for polypropylene?}

\section{Non-biological alternatives}

Nonabsorbable Polyvinylidene fluoride was first investigated in Canada in the mid 1990's as an alternative suture material to polypropylene in vascular surgery [29]. It soon turned out to feature advantageous physio-chemical and handling characteristics, as well as superior biocompatibility compared with PP. This might be an alternative.

\section{Biological alternatives}

Poly-4-hydroxybutyrate (P4HB), is a fully absorbable material with high mechanical strength, that is being studied as alternative to PP. For the indication of inguinal hernia P4HB is commercialized as Phasix (Bard $\left.{ }^{\circledR}\right)$. In vitro studies have been performed to research which knit-pattern has the best mechanical properties and most favorable cell-matrix interaction. Overall, P4HB appeared to induce more matrix deposition compared to PP [30]. Despite certain design and material characteristics that give the knitted P4HB implants a higher surface area, this did not result in more bacterial adhesion and biofilm formation overall [31, 32].

A human study has been initiated and so far, 18 patients have been included using this new biomaterial, this study was presented at IUGA 2019 but has not been published so far. To our knowledge, at this moment there are no other comparative alternatives to PP. 


\title{
Hier staat een advertentie.
}

\author{
$c$ bohn

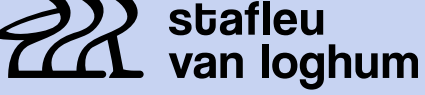 \\ Springer Media
}

Houten 2021 


\title{
Hier staat een advertentie.
}

\author{
$c$ bohn

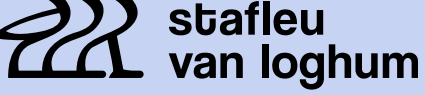 \\ Springer Media
}

Houten 2021 


\section{Comparison of various types of tapes}

An elegant study was published by Imamura et al. to compare the safety and effectiveness of the various surgical procedures for stress incontinence in women [33]. The authors studied RCT's evaluating surgical interventions for the treatment of stress urinary incontinence in women. The article comprised 175 RCT's assessing 21,598 women. Results showed that the interventions with highest cure rates were traditional sling, retropubic midurethral sling, open colposuspension, and transobturator tapes, with rankings of $89.4 \%, 89.1 \%, 76.7 \%$, and $64.1 \%$, respectively. Data on adverse events were available mainly for mesh procedures with a higher rate of repeat procedures and groin pain. However, a lower rate of suprapubic pain, vascular complications, bladder or urethral perforation, and voiding difficulties after transobturator MUS compared with retropubic tapes was seen. Data on adverse events for procedures other than with polypropylene were sparse with large confidence intervals. Long term data are sparse though. So the real RCT based comparison of polypropylene tapes compared to other surgical procedures shows that for cure, improvement and complications there is not much difference but there is a lack of specific data on non-polypropylene procedures.

Retropubic midurethral slings have a risk of bladder injury that has been reported as high as 5\% [34]. To reduce the risk on bladder injury, trans-obturator midurethral slings have been introduced [2]. With respect to trans-obturator slings, the risk of bladder perforation is proven to be lower as compared to retropubic slings, but the risk of leg pain or post-operative pain is higher [35, 36].

In patients with low urethral closure pressure, who are by many considered as having "intrinsic sphincter deficiency", retropubic tapes are associated with a statistically significant lower re-operation rate than transobturator slings [36].

The developments in single-incision mid-urethral slings (SIMS) are ongoing and are very promising. The first introduced SIMS (TVT-Secur) was associated with a significant failure rate, although post-operative pain was significantly lower than trans-obturator slings [37]. But apart from this TVT-Secur, several SIMS have shown to have non-inferior cure rates (as compared to transobturator slings) up to 36 months, with faster post-operative recovery and less post-operative pain [37].

\section{Which factors contribute to a successful outcome of stress incontinence surgery?}

\section{The patient factor}

Some factors determine for higher chance of success or failure. The presence of comorbidity, mixed urinary incontinence and advanced cystocele should be con- sidered high risk factors for persistent stress urinary incontinence in patients undergoing a MUS procedure [36, 38].

It has been demonstrated that older age, obesity and history of vaginal deliveries have no impact on objective and subjective sling effectiveness [39].

\section{Is handling by the surgeon important?}

Beyond patient factors, the surgeons' education and training with respect to anatomy, physiology, and technical skills remain the keystones of successful treatment. This is certainly a never-ending process as methods, devices, and concepts are frequently changing. Overall, there are "four rights" for good prolapse and continence surgery: only the right surgeon should place the right implant in the right patient using the right technique [20].

Scientific literature on the learning curves is scares. One should keep in mind that there are many different (41) sorts of MUS, and the techniques do differ. One of the eldest articles on the learning curve of the classical retropubic TVT showed a significant higher success rate when the surgeon had performed more than 20 procedures [40]. A recent Swedish study showed that there is a learning curve, but the small effect size shows no clinical significance. The authors concluded that training new TVT surgeons will not expose patients to extra risks and will achieve the same results as the most experienced surgeon [41].

This in contrast with the publication of Mowat in their 2016 study on surgical outcomes on low-volume vs high volume surgeons in gynecological surgery: a systematic review and meta-analysis. In this study a higher percentage of mesh complications was detected in low volume MUS surgeons [42]. These findings combined with the NICE advice in the UK on MUS, a certain volume of retropubic MUS per year by one surgeon seems recommendable [43].

\section{Conclusion and future}

The reputation of polypropylene mid-urethral slings for the surgical treatment of female SUI, has been severely damaged by the too early and to fast introduction of polypropylene meshes for vaginal surgical correction of POP. Due to the favorable risk/benefit ratio of PP slings and because of the consistently scientific documentation of all aspects of this surgery, the position as surgery of first choice will be re-established. Patients look for less invasive procedure and are willing to trade some efficacy for that. As a result, an increasing number of women may opt for bulking agents, especially when new technologies will be used to improve this intervention. With respect to PP slings there will be a shift towards shorter hospitalization and procedures in an office setting. Also, other concepts to stabilize hypermobile urethra will be presented in the coming decade. Last but not least, col- 
laboration with patient organizations worldwide has to result in even wider awareness about the condition and surgical solutions, so more women will be cured of bothersome SUI symptoms.

Conflict of interest J.P.F.A. Heesakkers is consultant for Boston Scientific International, Medtronic, Bluewind, Küste Biopharma. J.-P. Roovers is consultant for Coloplast, Tepha, Promedon. S.E. Schraffordt Koops is proctor for Intuitive Surgery.

Open Access This article is distributed under the terms of the Creative Commons Attribution 4.0 International License (http://creativecommons.org/licenses/by/4.0/), which permits unrestricted use, distribution, and reproduction in any medium, provided you give appropriate credit to the original author(s) and the source, provide a link to the Creative Commons license, and indicate if changes were made.

\section{References}

1. Ulmsten U, Petros P. Intravaginal slingplasty (IVS): an ambulatory surgical procedure for treatment of female urinary incontinence. Scand J Urol Nephrol. 1995;29:75-82.

2. FordAA, Rogerson L, CodyJD, AlukoP, OgahJA. Mid-urethral sling operations for stress urinary incontinence in women. Cochrane Database Syst Rev. 2017;7:CD6375.

3. US Food and Drug Administration. Urogynecologic surgical mesh: update on the safety and effectiveness of transvaginal placement for pelvic organ prolapse. 2011. https://www.fda.gov/downloads/medicaldevices/safety/ alertsandnotices/ucm262760.pdf. Accessed 15June2021.

4. US Food and Drug Administration. FDA's activities: urogynecologic surgical mesh.. https://www.fda. gov/medicaldevices/productsandmedicalprocedures/ implantsandprosthetics/urogynsurgicalmesh/ucm262301. htm. Accessed 15 June 2021.

5. Souders CP, Eilber KS, McClelland L, et al. The truth behind transvaginal mesh litigation: devices, timelines, and provider characteristics. Female Pelvic Med Reconstr Surg. 2018;24:21-5.

6. NHS surgery and procedures.. https://www.nhs.uk/ conditions/urinary-incontinence/surgery/. Accessed 15 June2021.

7. NICE. Recommendations urinary incontinence and pelvic organ prolapse in women: management guidance. 2019. https://www.nice.org.uk/guidance/ng123/ chapter/recommendations\#mid-urethral-mesh-slingprocedures. Accessed 15June 2021.

8. Cumberlege J. First do no harm. The report of the independent medicines and medical devices safety review. 2020. https://www.immdsreview.org.uk/Report.html. Accessed 15 June2021.

9. New Zealand Medicines and Medical Devices Safety Authority. Medsafe: regulatory action on surgical mesh products.. https://www.medsafe.govt.nz/hot/alerts/ UrogynaecologicaSurgicalMeshIm-plants.asp. Accessed 15 June 2021.

10. Australian Therapeutic Goods Administration. TGA actions after review into urogynaecologicalsurgical mesh implants.. https://www.tga.gov.au/alert/tga-actions-afterreview-urogynaecological-surgical-mesh-implants. Accessed 15 June 2021.

11. CodyJ, Wyness L, WallaceS. Systematic review of the clinical effectiveness and cost-effectiveness of tension-free vaginal tape for treatment of urinary stress incontinence. Health TechnolAssess. 2003;7(21):1-189.
12. MHRA. A summary of the evidence on the benefits and risks of vaginal mesh implants. 2014. https://assets.publishing. service.gov.uk/government/uploads/system/uploads/ attachment_data/file/402162/Summary_of_the_ evidence_on_the_benefits_and_risks_of_vaginal_mesh_ implants.pdf. Accessed 15 June 2021.

13. European Commission. Final opinion on the safety of surgical meshes used in urogynecological surgical meshes.. https://ec.europa.eu/health/scientific committees/consultations/public_consultations/ scenihr_consultation_27_en. Accessed 15June 2021.

14. ChappleCR, CruzF, ChappleXD, etal. Consensus statement of the European Urology Association and the European Urogynaecological Association on the use of implanted materials for treating pelvic organ prolapse and stress urinaryincontinence. Eur Urol. 2017;72:424-31.

15. Schraffordt Koops SE, Bisseling TM, Heintz APM, VervestHAM. Prospective analysis of complications of tensionfree vaginal tape from The Netherlands tension-free vaginal tape study. Am J Obstet Gynecol. 2005;193(1):45-52.

16. Hogewoning CRC, Gietelink L, Pelger RCM, et al. The introduction of mid-urethral slings: an evaluation of literature. Int Urogynecol J. 2015;26(2):229-34.

17. Haylen BT, Freeman RM, Swift SE, et al. An International Urogynecological Association (IUGA)/International Continence Society (ICS) joint terminology and classification of the complications related directly to the insertion of prostheses (meshes, implants, tapes) and grafts in female pelvic floor surgery. Neurourol Urodyn. 2011;30(1):2-12.

18. Maccraith E, Cunnane EM, Joyce M, et al. Comparison of synthetic mesh erosion and chronic pain rates after surgery for pelvic organ prolapse and stress urinary incontinence: a systematic review. Int Urogynecol J. 2021;32(3):573-580. https://doi.org/10.1007/s00192-020-04612-X.

19. Gurol-Urganci I, Geary RS, Mamza JB, et al. Longterm rate of mesh sling removal following midurethral mesh sling insertion among women with stress urinary incontinence supplemental content CME Quiz at jamanetwork.com/learning and CME questions page 1704. JAMA. 2018;320:1659-69.

20. Rovner E, De Tayrac R, Kirschner-Hermanns R, Veit-Rubin N, Anding R. Is polypropylene mesh material fundamentally safe for use as a reconstructive material in vaginal surgery: ICI-RS. Neurourol Urodyn. 2019;2020(39):132-9.

21. Cohen Tervaert JW. Autoinflammatory/autoimmunity syndrome induced by adjuvants (Shoenfeld's syndrome) in patients after a polypropylene mesh implantation. Best Pract Res Clin Rheumatol. 2018;32(4):511-20.

22. Chughtai B, Sedrakyan A, Mao J, et al. Is vaginal mesh a stimulus of autoimmune disease? Am J Obstet Gynecol. 2017;216:495.e1-495.e7.

23. Altman D, Rogers RG, Yin L, et al. Cancer risk after midurethral sling surgery using polypropylene mesh. Obstet Gynecol. 2018;131:469-74.

24. Lathe P, Lathe M, Say L, Gülmezoglu M, Khan KS. WHO systematic review of prevalence of chronic pelvic pain: a neglected reproductive health morbidity. BMC Public Health. 2006;6(6):177.

25. Karmakar D, Mostafa A, Abdel-Fattah M. Long-term outcomes of transobturator tapes in women with stress urinary incontinence: E-TOT randomised controlled trial. BJOG. 2017;124:973-81.

26. Kuhn A, Burkhard F, Eggemann C, Mueller MD. Sexual function after suburethral sling removal for dyspareunia. SurgEndosc. 2009;23:765-8. 
27. Jha S, Ammenbal M, Metwally M. Impact of incontinence surgery on sexual function: a systematic review and metaanalysis. J SexMed. 2012;9:34-43.

28. Alwaal A, Tian X, Huang Y, et al. Female sexual function following mid-urethral slings for the treatment of stress urinary incontinence. Int JImpot Res. 2016;28:121-6.

29. Urban E, King MW, Guidoin R, et al. Why make monofilament sutures out of polyvinylidene fluoride? ASAIO J. 1994;40:145-56.

30. Diedrich CM, Roovers JP, SmitTH, Guler Z. Fully absorbable poly-4-hydroxybutyrate implants exhibit more favorable cell-matrix interactions than polypropylene. Mater Sci Eng C. 2021;120:111702.

31. Verhorstert KWJ, et al. In Vitro bacterial adhesion and biofilm formation on fully absorbable poly-4-hydroxybutyrate and nonabsorbable polypropylene pelvic floor implants. ACS Appl Mater Interfaces. 2020;12:53646-53.

32. Verhorstert KWJ, Gudde AN, Kortz BS, et al. Animal experimental research assessing urogynecologic surgical mesh implants: Outcomemeasures describing the host response, a systematic review and meta-analysis. Neurourol Urodyn. 2021; https://doi.org/10.1002/nau.24677.

33. Imamura M, Hudson J, Wallace SA, et al. Surgical interventions for women with stress urinary incontinence: systematic review and network meta-analysis of randomised controlled trials. BMJ. 2019;365:11842.

34. Manca A, Sculpher MJ, Ward K, Hilton P. A cost-utility analysis of tension-free vaginal tape versus colposuspension for primary urodynamic stress incontinence. BJOG. 2003;110:255-62.

35. Novara G, Artibani W, Barber MD, et al. Updated systematic review and meta-analysis of the comparative data on colposuspensions, pubovaginal slings, and midurethral tapes in the surgical treatment of female stress urinary incontinence. Eur Urol. 2010;58(2):218-38.

36. Schierlitz L, et al. Effectiveness of tension-free vaginal tape compared with transobturator tape in women with stress urinary incontinence and intrinsic sphincter deficiency: a randomized controlled trial. Obstet Gynecol Clin North Am. 2008;112:1253-61.

37. Schellart RP, et al. A randomized comparison of a singleincisionmidurethralsling and atransobturatormidurethral sling in women with stress urinary incontinence: results of 12-mo follow-up. Eur Urol. 2014;66:1179-85.

38. Paick JS, Cho MC, Oh SJ, Kim SW, Ku JH. Factors influencing the outcome of mid urethral sling procedures for female urinaryincontinence. JUrol. 2007;178:985-9.

39. Majkusiak W, et al. Demographic risk factors for midurethral sling failure. Do they really matter? PLoS ONE. 2018; https://doi.org/10.1371/journal.pone.0207185.

40. Schraffordt Koops SE, Bisseling TM, van Brummen HJ, Heintz APM, Vervest HAM. What determines a successful tension-free vaginal tape? A prospective multicenter cohort study: results from the Netherlands TVT database. Am J Obstet Gynecol. 2006;194:65-74.

41. Nüssler EK, Löfgren M, Lindkvist H, Idahl A. The tensionfree vaginal tape operation: is the inexperienced surgeon a risk factor? Learning curve and Swedish quality reference. Acta Obstet Gynecol Scand. 2020; https://doi.org/10.1111/ aogs. 14033 .

42. Mowat A, Maher C, Ballard E. Surgical outcomes for lowvolume vs high-volume surgeons in gynecology surgery: a systematic review and meta-analysis. Am J Obstet Gynecol. 2016;215(1):21-33. https://doi.org/10.1016/j.ajog. 2016.02.048.

43. Urinary incontinence and pelvic organ prolapse in women: managementNICE guideline [NG123]. https://www.nice. org.uk/guidance/ng123. Published: 02 April 2019 Last updated: 24 June 2019

Prof. John P.F.A. Heesakkers, urologist

Prof. Jan-Paul Roovers, gynecologist

Steven E. Schraffordt Koops, gynecologist 